practically ready for publication. A research on the action of sodium and sodamide has been completed and the preparation and alkylation of cinchona alkaloid oxides is being studied.

ON the industrial side, important results have been obtained in fundamental research on carbon blacks. These have led to the development of a method for the colloidal dispersion of carbon black pigments in lacquer vehicles, which gives black lacquers of markedly improved properties. Other fellowship studies have shown that, by the use of aqueous dispersions of carbon black, maximum darkening of concrete can be obtained with a minimum ( 2 per cent) of pigment, with as much as 25 per cent greater strength in the concrete. Aqueous dispersions of carbon black for these purposes are being sold under the name 'Hiblak'. Other researches have led to the development of a new enamelling process, new building materials, including improved plastic cements and new sulphur cements for use as binding agents or protective coatings in structures subjected to acids or corrosive solutions. New methods for testing refractories have been developed while the fundamental investigations on sodium hexametaphosphate which have led to the development of 'Calgon' have been continued. Under a fellowship for organic synthesis, methods for the preparation of glycol ethers have been developed and improved, new types of vinyl resins examined, and a group of polyethyleneamine derivatives of ethylenediamine has been developed for use in gas purification. New uses for ethylene and morpholine amines have been discovered, and important work on dental caries and on atmospheric pollution has also been carried out.

\section{President Masaryk and Technology}

UNDER the title "T. G. Masaryk a Technika" the Masaryk Academy of Work has published an account of President Masaryk's contacts with science and his keen interest in the technical applications of pure science. It will be recalled that his early experiences at the blacksmith's forge proved of value to him in after life when he was professor of philosophy and later still in his capacity as President of the Czechoslovak Republic. Quite early in his university career, he drew up a classification of the sciences (afterwards much used and adapted on the Continent), dividing them into theoretical (abstract and concrete) and practical. He placed them into seven groups, showing their mergings and affinities. Without being a specialist in any branch, Prof. Masaryk was well versed in scientific method and became something of an expert in detecting forgeries. $\mathrm{He}$ endeavoured to direct his philosophy and science towards improving the amenities of mankind. Two quotations from his writings make clear his attitude. "In former times we went after things which struck our fancy, we went in search of gold, the philosophers' stone, the elixir of life. Now we analyse water, air, the soil, manure, everything ordinary that surrounds us." "Without work we shall never have sufficient selfconfidence. Work alone shows us what we are capable of. Work is self-recognition." The main part of the publication "T. G. Masaryk a Technika" has been compiled by Dr. V. Skrach; but a section on the origin of the Masaryk Academy of Work in 1920 is contributed by Prof. E. Zimmler, a former chairman. The Academy was founded as an autonomous scientific institution to organise technical work, making the best use of scientific advances and the natural resources of Czechoslovakia. It is composed of six sections: biological science and medicine, agriculture and forestry, building science, mechanics and electro-technics, chemistry and national economy. In its programme the Academy has combined all branches of engineering with the sciences, and has attempted to correlate research work and advances in the different sections so that they can be put to technical applications with the least possible delay.

\section{Longer Trade Cycles}

IN a pamphlet entitled "The Longer Trade Cycles" (Almquist and Wiksells Boktryckeri A-B., Stockholm, 1935), Axel F. Enström claims that a sixty year oscillation can be traced in a large number of price movements and production processes. An investigation of coal price quotations is said to have shown a complete sixty year period extending from about 1850 to 1910, while an examination of Sauerbeck's index number curve for wholesale prices disclosed the same cycle and in addition pointed to an earlier cycle of probably the same length. Valuable data illustrating price variations over a very long period, going back as far as the thirteenth century, are to be found in the Vicomte D'Avenal's monumental survey of French wheat prices, and an analysis of this material, according to Mr. Enström, shows a series of cycles of the order of magnitude of $60-50$ years. If the D'Avenal curve is examined in the light of purely qualitative evidence which French, Swedish and European history as a whole can give regarding economic events in the eighteenth and nineteenth centuries, it will be found that the $60-50$ year period of the curve accurately reflects the fluctuations in the European trade situation. The great technical inventions have as a rule been achieved in those periods which correspond to periods of depression in the superposed trade curve, that is, in periods characterised by a low price level.

\section{Recent Developments in Genetics}

The Nobel lecture given by Prof. T. H. Morgan at Stockholm on June 4, 1934, is printed in the Scientific Monthly of July 1935. In it Prof. Morgan reviews the progress of genetics, with special emphasis on recent developments. The nature of the gene is discussed, the position each occupies in the chromosome being regarded as probably in the nature of a historical accident. Linkage, translocation, the pairing of chromosome threads and the recent work on salivary gland chromosomes all yield evidence regarding the nature of the genes, but the manner of their growth and division remains hidden. The physiological properties of the genes and their 